\title{
The Development of a. Japanese SSW Test
}

\author{
by Floyd W. Rudmin
}

\section{Introduction}

The Staggered Spondaic Word (SSW) Test is a dichotic speech test for evaluating central auditory function (Katz, 1962). The test consists of 40 items each composed of a pair of spondaic words, i.e. "daylight" and "lunchtime". The pairs are matched so that the first part of the first word ("day") can be combined with the last part of the second word ("time") to form a third foil word ("daytime"). Spondaic words encourage correct responses by normals, and foil words encourage errors by abnormals. The two test words are presented dichotically in a partially ovarlapping manner. For example, as "daylight" is presented to one ear in the first channel, the onset of "lunchtime" to the other ear in the second channel is delayed so that "light" and "lunch" arrive at the same time and compete. The SSW Test is differentially sensitive to disorders in many regions of the cerebrum and brain stem, including cortical reception areas (Katz, 1963; 1968), various cortical non-auditory reception areas (Balas, 1971; Katz and Pack, 1975), cerebral auditory commissural tracts (Katz et al., 1975), auditory regions of the cerebellum (Katz, 1977), and upper vs. lower brain stem (Katz, 1970).

The SSW Test has several clinical strengths because its design includes: (1) common spondaic words, (2) a slow, clear, loud presentation, (3) a time staggered dichotic mode, and (4) a correction factor for word discrimination problems. The SSW is relatively insensitive to peripheral hearing loss and the resulting word discrimination problems. Normal subjects perform essentially without error and show little variability: after corrections for word discrimination, mean SSW scores for normals is about $2 \%$ error, with a standard deviation of about $2 \%$ (Brunt, 1972). Laterality effects due to hemispheric dominance for language is clinically insignificant (Brunt, 1972). The SSW is not sensitive to sex, intelligence, or socio-economic factors (Brunt, 1972). Finally, because the subjects' task is the identification of familiar words, the test is amenable to diverse populations, including children, the aged, the mentally retarded, schizophrenics, and patients hospitalized with CNS disorders (Brunt, 1972).

At present, there is no clinical audiological test in Japanese equivalent to the SSW Test (Tanaka, 1976). The objective of this study was to develop a staggered dichotic speech test in Japanese that will parallel the design of the SSW Test, List EC. The methodology was largely empirical. Two experiments were performed. The purpose of Experiment I was to select a class of Japanese words equivalent to English spondaic words, and to then select words within that class that are both familiar and appropriate for test items. The purpose of Experiment II was to record and dichotically align the test items similarly to the SSW Test, EC, and to then select those items for the final tapes that are most intelligible.

\section{Experiment I}

Since Japanese has no class of spondaic words, several feasible classes of words were considered: (1) Numbers with counters, i.e. "ni hiki" (two animals); (2) Twosyllable words, with each syllable words a morpheme represented by a single kanji, i.e. "hei wa" (peace); (3) Threesyllable words, i.e. "sumi e" (ink painting); and (4) Four-syllable words, i.e. "shiro kuma" (white bear). A syllable 
was defined as a peak of sonorancy, so that double duration vowels, as in "Kyüshū", or CVC combinatons,--as in "konbon", were counted as one syllable each. Most Japanese count syllables on the basis of hiragana orthography and would classify these words as four-syllable words, rather than as two-syllable words.

With the help of a Japanese language informant, 50 common words were selected for each class and recorded. Each word was preceded by the carrier phrase "tsugi wa" (Next is), and intensities were adjusted to have equal peak intensities, $\pm 2 \mathrm{~dB}$. The subjects were 8 adult native speakers of Japanese. All had normal hearing. Speech Reception Threshhold instructions (in Japanese) and 10 practice items were presented monaurally at $15 \mathrm{~dB}$ SL. Subsequent 10 item blocks were presented at successive $5 \mathrm{~dB}$ decrements, with the final presentation at $-5 \mathrm{~dB}$ SL. A questionnaire about the quality of the word lists and of the recording was completed by the subjects after the test.

The resulting intelligibility functions for the four classes of words, as well as for English spondaic words (Hirsh et al., 1952), were graphed. All four intelligibility functions were suitably similar to that of English spondaic words for use with a staggered dichotic speech test. However, four-syllable words were selected as the most appropriate because they had the lowest threshold of intelligibility ( $-1 \mathrm{~dB} \mathrm{SL})$, the greatest mean correct responses for each level $(6,22$ out of 10$)$, and the smallest mean standard deviation of errors (1.57). When four-syllable words are separated into component segments, i.e: "shiro" and "kuma", each segment is a complete word. The subjects' responses to the post-test questionnaire revealed that the words were common, that the recording quality was good, and that pronunciation speed was average. Five subjects reported the presence of an accent, and four of these felt that the pronunciation seemed unnatural and difficult to understand. Since none of the subjects spoke the same dialect as the speaker, the test results include dialect vartiables. The high performance of four-syllable words, despite dialect effects, indicates that they have some resistance to dialect distortion.

With the help of a Japanese language informant, a list of 90 pairs of matched four-syllable words was compiled. Words were selected to be common and not emotionally loaded (Broadbent, et al., 1967). Words were paired so that the non-competing segments could be combined to from a foil word. For example, "yūbin kyoku" (post office) paired with "denwa bango"" (telephone number) can yield the foil word "yūbin bangō" (postal code). This list of 90 pairs of four-syllable words was sent to 3 survey assistants in Japan. Each assistant interviewed: (1) a child under age 10 , (2) a teenager, (3) an adult male, (4)' an adult female, and (5) an adult over age 50 . These people were asked to select 20 items from the list of 90 that would be familiar and easy for children, and 20 to 30 items that would be unfamiliar or difficult for Japanese in general. Based on their judgements, 30 of the original 90 pairs of four-syllable words were eliminated. A recording script was prepared, consisting of the 60 remaining test items, 8 words for practice items, and instructions in Japanese.

\section{Experiment II}

An analysis of the SSW Test, List EC, revealed (1) that there is a slight unnatural pause between the two segments of each spondaic word, and (2) that the competing segments are dichotically aligned to have simultaneous centers. For example, the test item "meat sauce"/" base ball" can be perceived as a two-word task (to encourage correct responses by normal subjects) or as a fourword task (to encourage differential errors by abnormal subjects) because there is a slight unnatural pause splitting each spondaic word. Also, the competing segments "sauce" and "base" do not have simultaneous onsets, as is common with dichotic tests, but simultaneous centers, i.e. "base" begins $130 \mathrm{msec}$ after "sauce" but also ends $130 \mathrm{msec}$ before "sauce" ends. The 60 items for the Japanese experimental tape were recorded in standard Japanese by a native speaker. Although pitch contours 
for four-syllable words were maintained, slight pauses were introduced between segments. Thus, by pitch contours, "shiro kuma" can be perceived as one word, yet by the pause it can be perceived as two words. The 60 paired items were aligned dichotically to have simultaneous centers', $\pm 26 \mathrm{msec}$. Instructions and practice items were dubbed onto the experimental tape. The carrier phrase "De wa ii desu ka?"' (Are you ready?) preceded each test item in the lead channel. Intensity was adjusted so that competing segments had equal intensity, $\pm 4 \mathrm{~dB}$.

The subjects were 8 adult native Japanese with normal hearing bilaterally. Instructions in Japanese were presented at $30 \mathrm{~dB}$ SL. Practice items and the 60 dichotic test items were presented at $15 \mathrm{~dB}$ $\mathrm{SL}$. This low presentation level, rather than the $50 \mathrm{~dB}$ SL level used clinically, was necessary to challenge the normal subjects and thereby generate errors. Items were presented alternately left ear first, then right ear first, and so on. Half of the subjects began with the right ear first, half with. the left ear first. Errors were noted as omissions or as substitutions, which were transcribed phonetically. With 480 persentation ( 8 subjects $\times 60$ items) overall mean intelligibility was just over $85 \%$. 27 items were reported correctly by all 8 subjects, and 10 items accounted for over $50 \%$ of the errors. These 10 items and an additional 10 items were rejected from consideration for the final tapes. The arrangement of the remaining 40 items for the adult Japanese SSW Test, and the selection and arrangement of the easiest 20 items for the children's version of the test, were decided on the basis of intelligibility and familiarity. Katz (1977) indicates that the difficulty of the SSW Test, List EC, is not uniform, but that the first 10 items and the last 10 items are easier that the middle two blocks of 10 items. The test items for the final versions of the Japanese SSW Test were organized to have a similar difficulty pattern. (Copies of the final scripts and tapes may. be obtained from the author, at cost.)

\section{Discussion}

Obviously, this study represents a beginning, rather that the completion, of a project to develop a Japanese SSW Test for clinical use. The English and Japanese versions of the test have parallel designs. Errors made by subjects on the 60 dichotic items on the experimental tape were qualitatively similar to those that appear on the SSW Test during clinical use: there were a total of 37 omissions, 60 substitutions (5 involving the use of the foil word), and 3 reversals. Considering the 40 items selected for the adult version of the Japanese test, no laterality effects due to hemispheric dominance for language are apparent: out of 640 presentations per ear, there were 12 errors for each ear.

However, further studies need to be considered before these tapes can be adopted for clinical use. Considering the 40 items selected for the adult version, the leading four-syllable words had more errors (16) than the lagging four-syllable words (2). This type of "lag effect" has been reported by others (Porter et al., 1969; Studdert-Kennedy et al., 1970; Katz, 1977), and may be inherent in dichotic testing. The magnitude of the "lag effect" in this study may be due to low presentation level and/or to the dubbing and alignment techniques. This requires further study. Also, the tapes need to be tested with larger populations of normal subjects to quantify the effects, if any, of age, intelligence, educational background, and dialect. Normal subjects with peripheral hearing loss need to be tested to determine if Japanese SSW dichotic intelligibility correlates with monaural word discrimination scores. Because the SSW scores have a high correlation $(r=.93)$ with word discrimination scores, a correction factor for peripheral disorders is possible (Katz et al., 1963). Finally, it is crucial to establish the ability of the Japanese SSW Test to locate central auditory disorders. 


\title{
抄 録
}

\section{日本語 SSWテストの考案}

\author{
Floyd W. Rudmin
}

\section{諸外国及び諸外国語で用いられている中枢性聴覚テ} ストについては今日その基準化が必要となっている。 Staggered Spondaic Word（SSW）テストは中枢性 聴覚機能をテストする一種の dichotic speech test で ある。このテストは 2 音節語よりなり，2チャネルテ 一プK，第 1 チャネルの語の第 2 音節と第 2 于ャネル の第 1 音節が重なり合うよろに録音し，両耳に与える あのである。SSW は Heschl の横回や，その他の大 脳皮質領野, 上部脳幹, 下部脳幹を含む中枢性聴觉系 のいろいるな部位の障害汇敏感である。SSW は，(1) 正常な被検者飞とっては極めてやさしく，(2)末梢性聴 力障害があっても差しつかえがなく，(3大脳半球の優 位性飞影響されず，(3いろいろな領野の人びとに適合 する，などの点で強力な中枢性聴党テストといえる。 SSW をモデル沉した検査法が数か国で考案された が，本研究の目的は，SSW をデザインとしてそれに 匹敵する日本語の検查を作成することにある。

実験 Iは，SSW の spondee words K㥵当する日 本語の単語リストを作成することを目的とした。この ためにまず次の 4 クラスを考虑した。すなわち，(1)物 や動物の数元方（たと光ば「2匹」)，(2) 2 音節語でそ の音節が漢字で表わされるもの, (3) 3 音節単語（たと えば「畦絵」), (4) 4 音節単語 (たとえば「白熊」)。こ れらの音節は仮名単位よりも sonorancy のピーク数 飞よって決めた。各クラスとも日常よく使われること ぼ50語を録音し, 日本人 8 名汇域值付近の強さで 1 側 耳にきかせた。そして，明瞭度関数 (intelligibility function）をむとに， spondee word に最も匹適する あのとして 4 音節語を選んだ。次いで，第 1 語の前半 部を第 2 音の後半部と組み合せて第 3 の 4 音節語を作 るという方式で，90組の日常的な 4 音節語を作成した （たとえぼ郵便局と電話番号を組み合せて 郵便番号と するようと)。これら 90 組の単語飞ついては, 日本在 住の 3 名の研究協力者が，打の打の 5 名の代表的日本 人反依賴して，その精通度扔よび難易度を判定しても らった。これらの判定にもとずいて60組の用語を録音 用江逥定した。
実験 II では，日本語 staggered dichotic test の最 終版を作るべく，最良の dichotic intelligibility を有 する語の組み合せを選択した。まず，準備段階として 60 組の語を各語とも前後 2 音節間炕わずかの間を置い て（たとえ龵便と局の間に），標準日本語で 録音し た。この場合， 2 チャネルで重なり合う音節部分は， それらの出だしを揃えるよりも音の中央が同時になる ように配列した。実験テープには初めの部分に日本語 による検查の指示と 4 個の練習項目を加え，8名の日 本人被検者に $15 \mathrm{dBSL}$ にて与光た。この dichotic intelligbility の成續飞基ずいて40組を日本語 staggered dichotic test 用語として選出し, SSW の難易度 飞応じて子供用リスト 20 組と成人用リスト 40 組を作成 した。

ところで，この日本語 staggered dichotic test が 臨床上 SSW 飞匹敵するかどうか恃 今後更に検討を 要するがしかしながらこれまでの実験的テストによ ると，日本人被検者飞みられた愦りは SSW テストて 生じたものに類似している。また第 2 語（遅れてきこ 劣る語）飞括ける誤りは第 1 語（最初にきこえてくる 語）飞比べてより少ない傾向がみられた。この“遲延 効果 (lag effect)”は SSW テストやその他の dichotic test 飞扔いてもすで報告されている。また，最終成 人用リスト 40 組飞怙いては大脳半球優位効果はみられ なかったし, $15 \mathrm{~dB}$ SL そ招ける dichotic intelligibility は $20 \mathrm{dBSL}$ K扔ける SSW テストのそれよりはるか 飞良好であった。このテストを臨床的活用するに当 っては，それ以前飞多数の正常な聴力者についている いろな特性の影響を吟味して和く必要があり，また末 梢性の語言弁別障害を修正する手段の確立，ならびそ 限局性中枢神経障害を有する患者の反応パターン飞つ いても研究して置く必要がある。

（本論文は 紙数の関係で 細部にわたってまでは述べ られていない。本法の詳細について興味のある方は帝 京大学医学部耳鼻咽喉科学教室 田中美鄉汃, あるい は直接著者他照会願いたい)。 


\section{References}

Balas, R.F.: Staggered spondaic word test: support. Ann. Otol. Rhinol. Laryngol. 80: 132134 (1971).

Broadbent, D. E. and Gregory, M.: Perception of emotionally toned words. Nature Lond. 215: 581-584 (1967).

Brunt, M. A.: The staggered spondaic word test. In J. Katz (ed.): Handbook of clinical audiology (Williams \& Wilkins, Baltimore. 1972).

Hirsh, I. J., Davis, H., Silverman, S. R., Reynolds, E.G., Eldert, E. and Benson, R.W.: Development of materials for speech audiometry. J. Speech Hearing Dis. 17: 321-337 (1952).

Katz, J.: The use of staggered spondaic words for assessing the integrity of the central auditory nervous system. J. . Aud. Res. 2: 327337 (1962).

Katz, J.: The SSW test: an interim report. J. - Speech Hearing Dis. 33: 132-146 (1968).

Katz, J.: Audiologic diagnosis: cochlea to cortex. Menorah Med. J. 1; 26-36 (1970).

Katz, J.: Personal communication (1977).

Katz, J., Basil, R. and Smith, J.: A staggered 1 spondaic word test for detecting central audi- tory lesions. Ann. Otol. Rhinol. Laryngol. 72: 908-918 (1963).

Katz, J., Küshner, D. and Pack, G.: The use of competing speech (SSW) and environmental sound (CES) tests for localizing brain lesions. Presented at Am. Speech Hearing Assoc. Meeting, Washington, D. C. (1975).

Katz, J. and Pack, G.: New developments in differential diagnosis using the SSW test. In M. Sullivan (ed.): Central Auditory processing disorders (U. of Nebraska, Omaha, 1975).

Porter, R., Shankweiler, D. and Liberman, A.: Differential effects of binaural time differences on perception of stop consonants and vowels. Proceedings of 77th Annual Meeting of Am. Psychol. Assoc., Washington, D. C. (1969).

Studdert-Kennedy, M., Shankweiler, D. and Schhulman, S.: Opposed effects of a delayed channel on perception of dichotically and monotically presented CV syllables. J. Acoust. Soc. Amer. 48: 599-602 (1970).

Tanaka, Y.: Personal communication (1976). 受付 53. 1. 17)

著者連絡先：Apt. D-1904, 350 Prince Arthur Montreal, P.Q. H2X3R4, Canada 